\title{
A BRIEF ASSESSMENT OF COMPLIANCE WITH THE "EUROPE 2020" STRATEGY CRITERIA OF MEMBER STATES OF THE EUROPEAN UNION
}

\author{
PAPAGEORgIOU CHRISTOS ${ }^{\mathrm{i}}$, ANASTASIOU ATHANASIOS ${ }^{\mathrm{ii}}$, DeRMATIS ZACHARIAS ${ }^{\mathrm{iii}}$
}

\begin{abstract}
Eight indicators corresponding to the targets of "Europe 2020" Strategy were used to estimate the deviation of EU Member-States from their targets. The study showed that: i) the distance to the employment target of $75 \%$ of people aged 20-64 years has narrowed, ii) the expenditure for $R \& D$ as a percentage of GDP are still below the target of $3 \%$, iii) the reduction of greenhouse gas emissions in ESD sectors by $20 \%$ compared to 1990 levels are still below the target, iv) the increase of the share of renewable energy in final consumption to $20 \%$ remains just below the target, $v$ ) the move towards a $20 \%$ increase in energy efficiency shows a good prospect, vi) the reduction of school drop-out rates to less than $10 \%$ is steadily approaching its target, vii) the share of population aged 30-34 having completed tertiary education to at least $40 \%$ is steadily approaching its target, viii) the lifting at least 20 million people out of risk of poverty was not achieved.
\end{abstract}

Keywords: “Europe 2020” Strategy, smart growth, sustainable growth, inclusive growth.

\section{THE "EUROPE 2020" STRATEGY - SCOPE OF STUdY}

The "Europe 2020" Strategy proposed by the Commission on 3 March 2010 and adopted by the European Council on 26 March 2010 set three priorities to promote growth: (a) smart, with more efficient investment in education, research and development and innovation, (b) sustainable, with transition to a low

\footnotetext{
${ }^{\text {i }}$ Doctor in Professional Studies, Middlesex University U.K, PhD in Assessment of European Economic Integration, University of Peloponnese Greece

ii Associate Professor of Department of Management and Technology, University of Peloponnese Greece, Workshop of Sustainable Development and Entrepreneurship

iii $\mathrm{PhD}$, Department of Management and Technology, University of Peloponnese Greece, Workshop of Sustainable Development and Entrepreneurship
} 
carbon economy, share of renewable energy and increase in energy efficiency, (c) inclusive, with a focus on job creation and poverty reduction (European Commission, 2010, 2012, 2014).

Five key EU-wide objectives have been agreed to assess the progress made in implementing the "Europe 2020" Strategy: (a) employment, (b) research and development, (c) climate change and energy sustainability, (d) education and (e) combating poverty and social exclusion. To reach the objectives, the EU has adopted eight ambitious targets at EU level. These targets are then converted into national targets for each Member State, reflecting the different situations, conditions and abilities in each Member State (Fischer et al., 2010, Hacker \& Treek, 2010, Anastasiou \& Pasiopoulou, 2020, Papailiou et al., 2018, Zavou et al., 2018, Lyroni et al., 2018).

For the employment target it is foreseen to increase employment in the age group 20-64 from $69 \%$ to at least $75 \%$. For the R\&D target, it is foreseen that $3 \%$ of EU GDP should be invested in R\&D. For the target of climate change and energy sustainability it is foreseen to reduce greenhouse gas emissions by $20 \%$ (or even $30 \%$ if conditions allow) compared to 1990 , to secure $20 \%$ of renewable energy and a $20 \%$ increase in energy efficiency (Aggelopoulos et al., 2018). For the target of education it is foreseen to reduce early school dropout rates from $15 \%$ to less than $10 \%$ and complete higher education in the age group of 30-34 from $31 \%$ to at least $40 \%$. For the target of combating poverty and social exclusion it is foreseen to be reduced by at least $20 \%$, i.e. by 20 million people who are or will be at risk of poverty and social exclusion. The following Table 4 illustrates the objectives and the targets of "Europe 2020" Strategy.

Table 1 Targets and Objectives of "Europe 2020" Strategy

\begin{tabular}{c|l|l|l|} 
Priorities & \multicolumn{2}{|c|}{ Objectives } & \multicolumn{1}{c}{ Targets } \\
\hline $\begin{array}{l}\text { Smart } \\
\text { growth }\end{array}$ & R\&D & in & $\begin{array}{l}\text { - Increasing combined public and private investment } \\
\text { in R\&D to 3\% of GDP }\end{array}$ \\
& Education & $\begin{array}{l}\text { - Reducing school drop-out rates to less than } 10 \% \\
\text { - Increasing the share of the population aged } 30-34 \\
\text { having completed tertiary education to at least } 40 \%\end{array}$
\end{tabular}




\begin{tabular}{|c|c|c|}
\hline Priorities & Objectives & Targets \\
\hline $\begin{array}{l}\text { Sustainable } \\
\text { Growth }\end{array}$ & Climate Change & $\begin{array}{l}\text { - Reducing greenhouse gas emissions by at least } 20 \\
\text { \% compared to } 1990 \text { levels } \\
\text { - Increasing the share of renewable energy in final } \\
\text { energy consumption to } 20 \% \\
\text { - Moving towards a } 20 \% \text { increase in energy } \\
\text { efficiency }\end{array}$ \\
\hline \multirow{2}{*}{$\begin{array}{l}\text { Inclusive } \\
\text { Growth }\end{array}$} & Employment & $\begin{array}{l}\text { - Increasing the employment rate of the population } \\
\text { aged 20-64 to at least } 75 \%\end{array}$ \\
\hline & $\begin{array}{l}\text { Combating } \\
\text { Poverty \& } \\
\text { Exclusion }\end{array}$ & $\begin{array}{l}\text { - Lifting at least } 20 \text { million people out of the risk of } \\
\text { poverty and social exclusion }\end{array}$ \\
\hline
\end{tabular}

Source: European Commission (2020), modified by the author

Member States are committed to achieving the objectives of the "Europe 2020" Strategy, which they have turned into national targets. However, the desired results for development can be achieved only with the coordination and proper targeting of efforts at national level. The Commission has introduced the "European Semester", a cycle of economic policy coordination. The European Council of 17 June 2010 endorsed the idea of the "European Semester". Each year, the Commission gives a detailed breakdown of the budgetary, macroeconomic and structural reforms programme for each Member State, and makes recommendations for the next 12-18 months.

The scope of this study is the estimation of the deviation of all MemberStates from the targets set by each state during the years 2008 - 2018. Recent available data from Eurostat (2019) will be used to estimate the current deviation from targets for each Member-State and to rank all of them according to this deviation (Gros \& Roth, 2012).

\section{Calculation of “Europe 2020” Strategy INDiCators}

Eight normalized indicators corresponding to the targets presented in Table 1 will be calculated. Data and targets for each Member-State have been extracted from Eurostat (2019) data bases. Data and targets for all states are presented in Appendix.

Following the description of the objectives of "Europe 2020" Strategy, the following indicators will be calculated, using the corresponding data and targets: 
1. Employment indicator:

$$
\boldsymbol{E} \boldsymbol{M} \boldsymbol{P}_{i, t}=\frac{e m p_{i, t}-e m p_{i, \tau}}{e m p_{i, \tau}}
$$

where:

$\mathbf{E M P}_{\mathbf{i}, \mathbf{t}}=$ is the normalized employment idicator of Member State $\mathrm{i}$ during year $\mathrm{t}$

$\mathbf{e m p}_{\mathbf{i}, \mathrm{t}}=$ is the employment rate of Member State i during year $\mathrm{t}$ as $\%$ of age group 20-64

$\mathbf{e m p}_{\mathbf{i}, \tau}=$ is the employment rate target of Member State $\mathrm{i}$ as $\%$ of age group 20-64

2. Research and Development indicator:

where:

$$
R \& D_{i, t}=\frac{r \& d_{i, t}-r \& d_{i, \tau}}{r \& d_{i, \tau}}
$$

$\mathbf{R} \& \mathbf{D}_{\mathbf{i}, \mathbf{t}}=$ is the normalized research and development indicator of Member State $\mathrm{i}$ during year $\mathrm{t}$

$\mathbf{r} \& \mathbf{d}_{\mathbf{i}, \mathbf{t}}=$ is the research and development expenditure of Member State $\mathrm{i}$ during year $\mathrm{t}$ as $\%$ of $\mathrm{GDP}_{\mathrm{i}, \mathrm{t}}$

$\mathbf{r} \& \mathbf{d}_{\mathbf{i}, \tau}=$ is the research and development expenditure target of Member

State i as \% of GDP $\mathrm{P}_{\mathrm{i}, \mathrm{t}}$

3. Climate Change and Energy indicator A:

where:

$$
C E A_{i, t}=\frac{c e a_{i, \tau}-c e a_{i, t}}{c e a_{i, \tau}}
$$

$\mathbf{C E A}_{\mathbf{i}, \mathrm{t}}=$ is the normalized climate change $1^{\text {st }}$ idicator of Member State $\mathrm{i}$ during year $\mathrm{t}$

$\mathbf{c e a}_{\mathbf{i}, \mathbf{t}}=$ is the greenhouse gas emissions of Member State $\mathrm{i}$ during year $\mathrm{t}$ compared to 1990 levels

$\mathbf{c e a}_{\mathbf{i}, \tau}=$ is the greenhouse gas emissions target of Member State i compared to 1990 levels

4. Climate Change and Energy indicator B:

where:

$$
C E B_{i, t}=\frac{c e b_{i, t}-c e b_{i, \tau}}{c e b_{i, \tau}}
$$

$\mathbf{C E B}_{\mathrm{i}, \mathrm{t}}=$ is the normalized climate change $2^{\text {nd }}$ idicator of Member State $\mathrm{i}$ during year $\mathrm{t}$

$\mathbf{c e b}_{\mathbf{i}, \mathbf{t}}=$ is the share of renewable energy of Member State i during year $\mathrm{t}$ in final consumption $\%$

$\mathbf{c e b}_{\mathbf{i}, \tau}=$ is the share of renewable energy target of Member State $\mathrm{i}$ in final consumption \% 
5. Climate Change and Energy indicator $\mathrm{C}$ :

where:

$$
C E C_{i, t}=\frac{\operatorname{cec}_{i, \tau}-\operatorname{cec}_{i, t}}{\operatorname{cec}_{i, \tau}}
$$

$\mathbf{C E C}_{\mathrm{i}, \mathrm{t}}=$ is the normalized climate change $3^{\text {rd }}$ idicator of Member State $\mathrm{i}$ during year $\mathrm{t}$

$\mathbf{c e c}_{\mathrm{i}, \mathrm{t}}=$ is the final energy consumption of Member State i during year $\mathrm{t}$ in Mtoe

$\mathbf{c e c}_{\mathbf{i}, \tau}=$ is the final energy consumption target of Member State $\mathrm{i}$ in Mtoe

6. Education indicator A:

where:

$$
E D A_{i, t}=\frac{e d a_{i, \tau}-e d a_{i, t}}{e d a_{i, \tau}}
$$

$\mathbf{E D A}_{\mathrm{i}, \mathrm{t}}=$ is the normalized education $1^{\text {st }}$ idicator of Member State $\mathrm{i}$ during year $\mathrm{t}$

$\mathbf{e d a}_{\mathbf{i}, \mathrm{t}}=$ is the early leavers from education and training of Member State $\mathrm{i}$ during year $t$ as $\%$ of population aged 18-24

$\mathbf{e d a}_{\mathbf{i}, \tau}=$ is the early leavers from education and training target of Member State $i$ as $\%$ of population aged $18-24$

7. Education indicator B:

where:

$$
E D B_{i, t}=\frac{e d b_{i, t}-e d b_{i, \tau}}{e d b_{i, \tau}}
$$

$\mathbf{E D B}_{\mathrm{i}, \mathrm{t}}=$ is the normalized education $2^{\text {nd }}$ idicator of Member State i during year $\mathrm{t}$

$\mathbf{e d b}_{\mathbf{i}, \mathrm{t}}=$ is the tertiary educational attainment of Member State i during year $\mathrm{t}$ as $\%$ of population aged $30-34$

$\mathbf{e d b}_{\mathbf{i}, \tau}=$ is the tertiary educational attainment target of Member State i as \% of population aged 30-34

8. People at Risk of Poverty indicator:

where:

$$
P O V_{i, t}=\frac{\operatorname{pov}_{i, \tau}-\operatorname{pov}_{i, t}}{\operatorname{pov}_{i, \tau}}
$$

$\mathbf{P O V}_{\mathrm{i}, \mathrm{t}}=$ is the normalized people at risk of poverty idicator of Member

State i during year $\mathrm{t}$

$\operatorname{pov}_{\mathrm{i}, \mathrm{t}}=$ is the people at risk of poverty or social exclusion of Member State i during year $t$ in thousands

$\operatorname{pov}_{\mathbf{t}, \tau}=$ is the people at risk of poverty or social exclusion target of Member State i in thousands 
Variables with capital letters refer to the final normalized indicators, while variables with lowercase letters refer to either target values (with index t) or values for a specific year (with index i). Obviously, if the value for a specific year equals to the target value, then the indicator value equals to 0 (zero). If the values of a specific year exceed the target values (ie if $\boldsymbol{e m p}_{i, t}>\boldsymbol{e} \boldsymbol{m} \boldsymbol{p}_{\boldsymbol{i}, \tau}, \boldsymbol{r} \boldsymbol{\&} \boldsymbol{d}_{i, t}>\boldsymbol{r} \boldsymbol{\&} \boldsymbol{d}_{\boldsymbol{i}, \tau}$, $c e a_{i, \tau}>c e a_{i, t}, c e b_{i, t}>c e b_{i, \tau}, c e c_{i, \tau}>c e c_{i, t}, e d a_{i, \tau}>e d a_{i, t}, e d b_{i, t}>e d b_{i, \tau}, \operatorname{pov}_{i, \tau}>$ $\operatorname{pov}_{i, t}$ ), then the values of the final indicators are positive, while if this is not the case then the values of the final indicators are negative.

Total deviations from targets are calculated using only the negative values of the indicators, since zero and positive values mean that the targets have been reached.

\section{RESULTS AND DISCUSSION}

The obtained results for all Member-States and all targets of "Europe 2020" Strategy for years $2008-2018$ are given in the following Figures $1-8$ which illustrate graphically the change of all indicators for all EU28 Member-States. Also, Table 2 illustrates the starting and the recent deviations from targets for all indicators of Strategy "Europe 2020" and the total deviations for all Member States. It shows how far a Member-State is from its targets by comparing the national target (blue line), the country's indicators in 2008 (yellow line) and the recent indicators (red line).

From the obtained results and for each of the eight indicators it is clear that:

1. Employment indicator (Increasing the employment rate of the population aged 20-64 to at least $75 \%$ ). EU15 Member States obviously have been affected widely by the recent global economic crisis, and as a recult, the employment rate of age group 20-64 was reduced from year 2008 untill year 2013 for most Member-States, with the sxception of Germany and Sweden, where the employment rate have almost not been affected by the economic crisis. Recent data show that most of the Member-States of EU15 could not reach the figures of year 2008 yet, meaning that there is an increase in the deviation from final targets for most Member-States of EU15. On the other hand, EU13 Member-States, although they have been affected by the global economic crisis, they reacted more efficiently, and as a result, most of them have reached their taergets, while the rest of them show a considerable decrease in their deviation from their target. But although the mean deviation of all EU Member-States is recently smaller than that 
of year 2008, mainly due to the behaviour of the EU13 Member-States, more effort is required especially from the EU15 Member-States, in order the average target for EU Member-States to be reached within the next two years.

2. Research and Development indicator (Increasing combined public and private investment in R\&D to $3 \%$ of GDP). With the exception of Germany and Denmark, the rest of EU15 Member-States did not rach their target. Actually, their expenditures for research and development as \% of GDP, did not increase considerably for years 2008-2018. For EU13 and with the exception of Czechia, for which the target includes public sector only and is set to 1\% of GDP, Cyprus is the only Member-State reached the target. As a result, the mean deviation of all EU Member-States is recently (2018) smaller than that of year 2008, but there is a lot to be done in order the average target for EU Member-States to be reached, especially from the EU13 Member-States.

3. Climate Change and Energy indicator A (Reducing greenhouse gas emissions in ESD sectors by at least $20 \%$ compared to 1990 levels). Almost all EU15 Member-States have decreased their deviations from their targets, with the exception of Ireland. Seven Member-States have reached their final targets, among them Greece and Portugal which had reached their targets since 2008. Most of EU13 Member-States had reached their targets from year 2008, but their positive distance from targets in 2018 was decreased, while Poland and Malta, although they had indicators values above the darget during 2008, their indicators during 2018 are below the target. More effort is required from some EU15 and EU13 Member-States in order the everage target for EU Member-States to be reached.

4. Climate Change and Energy indicator B (Increasing the share of renewable energy in final energy consumption to $20 \%$ ). All Member-States of EU15 are approaching significantly their final targets. Netherlanfs is the Member-State with the largest deviation from its target, while five Member-States have already reached their targets. From the E13 Member-States, six states have already reached their targets, from which, Croatia had reached its target since 2008. The rerst of them are approachiung their targets significantly. As a result, the deviation from the everage target for all EU Member-States was decreased significantly, showing a good prospect for this indicator. 
5. Climate Change and Energy indicator $\mathrm{C}$ (Moving towards a $20 \%$ increase in energy efficiency). All Member-States of EU15 are approaching significantly their final targets, while five Member-States have already reached their targets, from which, Finland had reached its target since 2008. From the E13 Member-States, seven states have already reached their targets, from which, five states had reached their targets since 2008. The rest of them are approachiung their targets significantly. As a result, the deviation from the everage target for all EU Member-States was decreased significantly, showing a good prospect for this indicator. Note that the target for all EU Member-States was almost reached during 2014.

6. Education indicator A (Reducing school drop-out rates to less than $10 \%$ ). Almost all Member-States of EU15 showed a very good behaviour in approaching and reaching their targets and eight of them have already reached their targets. Four Member-States of EU13 have already reached their targets, among which Lithuania which had reached its target since 2008, while the rest of them are approachiung their targets significantly, with the exception of Slovakia which although it had indicator value above the darget during 2008, its indicator during 2018 is below the target. The deviation from the average target for all EU Member-States was decreased significantly, showing a good prospect for this indicator.

7. Education indicator B (Increasing the share of the population aged 30-34 having completed tertiary education to at least $40 \%$ ). Nine Member-States of EU15 have already reached their final targets, from which, Finland had reached its target since 2008. The other six Member-States are approachiung their targets significantly. Also, eight Member-States of EU13 have already reached their final targets, from which, Cyprus had reached its target since 2008. The other five Member-States are approachiung their targets significantly. The average target for all EU Member-States has already reached, showing a good prospect for this indicator.

8. People at Risk of Poverty indicator (Lifting at least 20 million people out of the risk of poverty and social exclusion). Only two Member-States of EU15 have already reached their final targets, while other Member-States like Greece, Spain, Ireland and Italy have been affected by the global economic crisis. Luxembourg increased its deviation from the final target due to the difficult target set by it. 
Also, eight Member-States of EU13 have already reached their final targets, while from the rest Member-States Estonia and Cyprus increased their deviation from the final target, mainly due to the economic crisis. More effort is required from mainly EU15 and some EU13 Member-States in order the average target for EU Member-States to be reached.

\section{CONCLUSIONS}

Generally for all EU Member-States, i) the distance to the employment target of $75 \%$ of people aged 20-64 years has narrowed but more effort is required especially from the EU15 Member-States, ii) the expenditure for R\&D as a percentage of GDP are still below the target of 3\%, which calls for increasing combined public and private $R \& D$ expenditure, iii) the reduction of greenhouse gas emissions in ESD sectors by at least $20 \%$ compared to 1990 levels are still below the target and more effort is required from some Member-States, iv) the increase of the share of renewable energy in final energy consumption to $20 \%$ remains just below the target, showing a good prospect from almost all Member-States, v) the move towards a $20 \%$ increase in energy efficiency was significant showing a good prospect from almost all Member-States, vi) the reduction of school drop-out rates to less than $10 \%$ is steadily approaching its target, vii) the increase of the share of the population aged 30-34 having completed tertiary education to at least $40 \%$ is also steadily approaching its target, viii) the lifting at least 20 million people out of the risk of poverty and social exclusion was not achieved and more effort is required from mainly EU15 and some EU13 Member-State. 


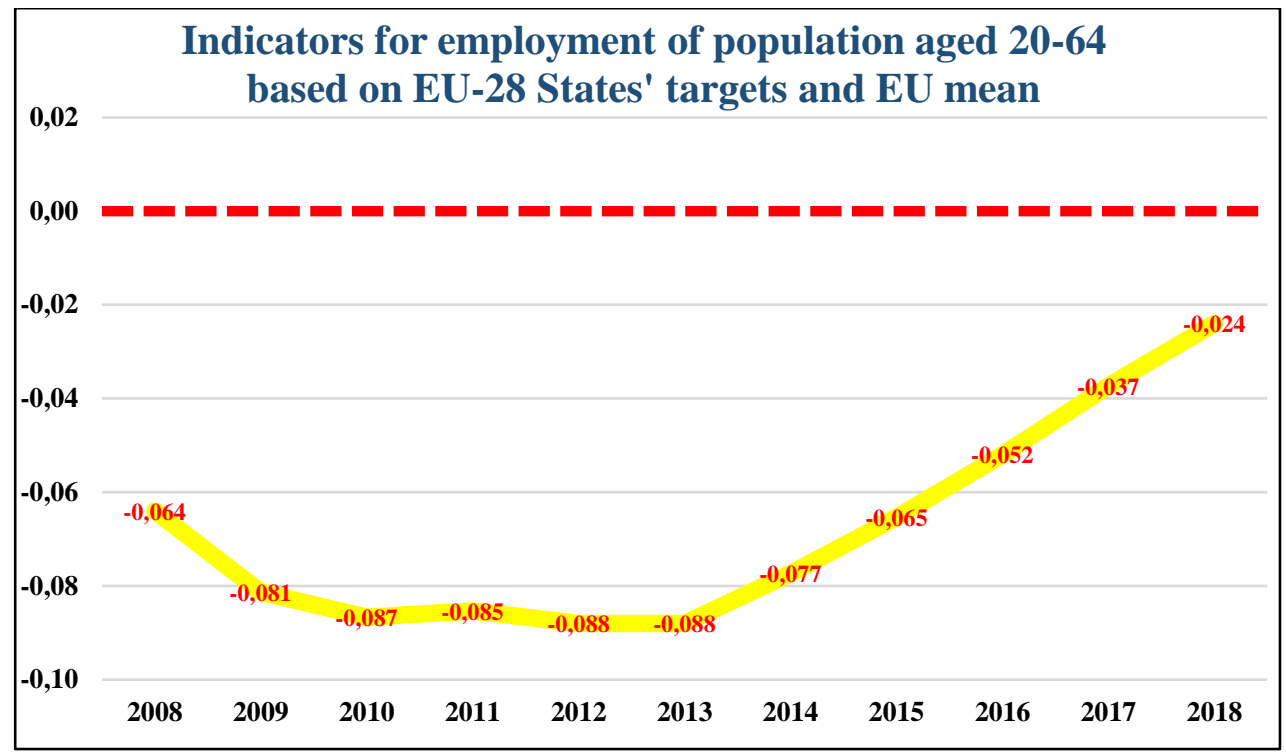

Figure 1 Indicators for employment of population aged 20-64 based on EU-28 States' targets and EU mean.

Source: Author's calculations

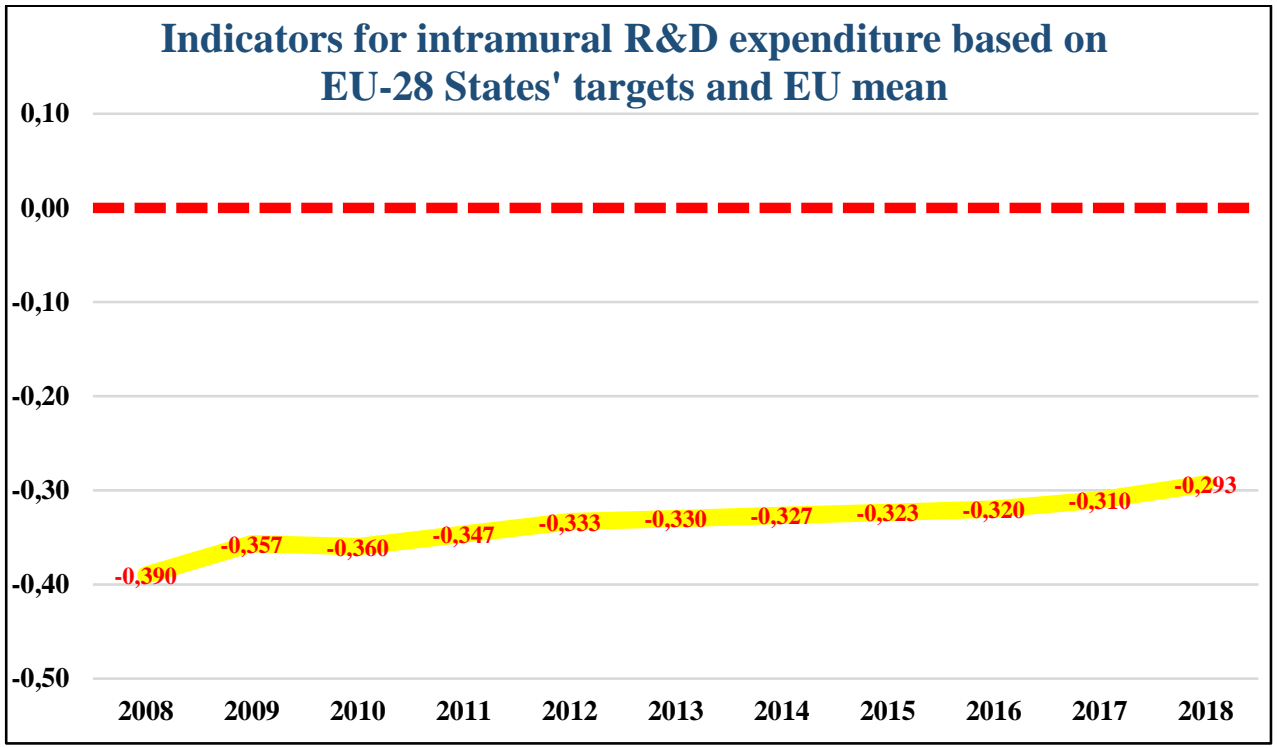

Figure 2 Indicators for intramural R\&D expenditure based on EU-28 States' targets and EU mean

Source: Author's calculations 


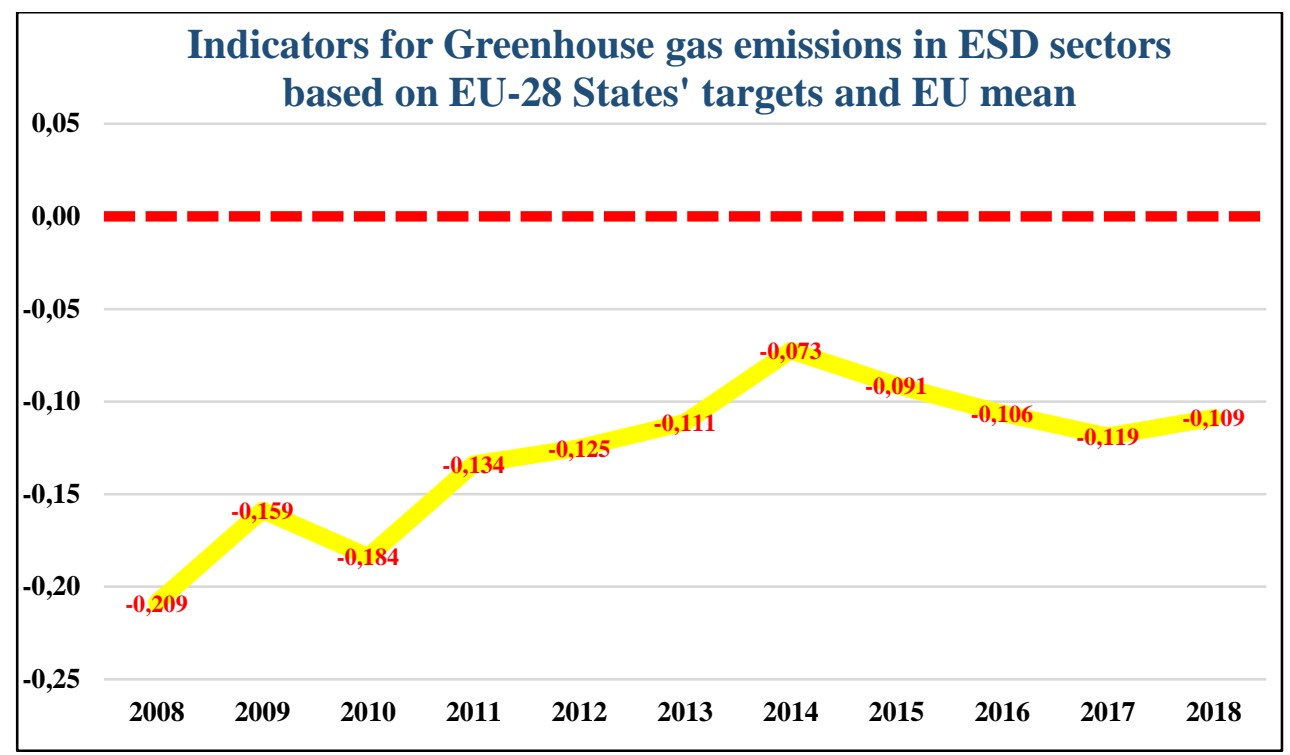

Figure 3 Indicators for Greenhouse gas emissions in ESD sectors based on EU-28 States' targets and EU mean.

Source: Author's calculations

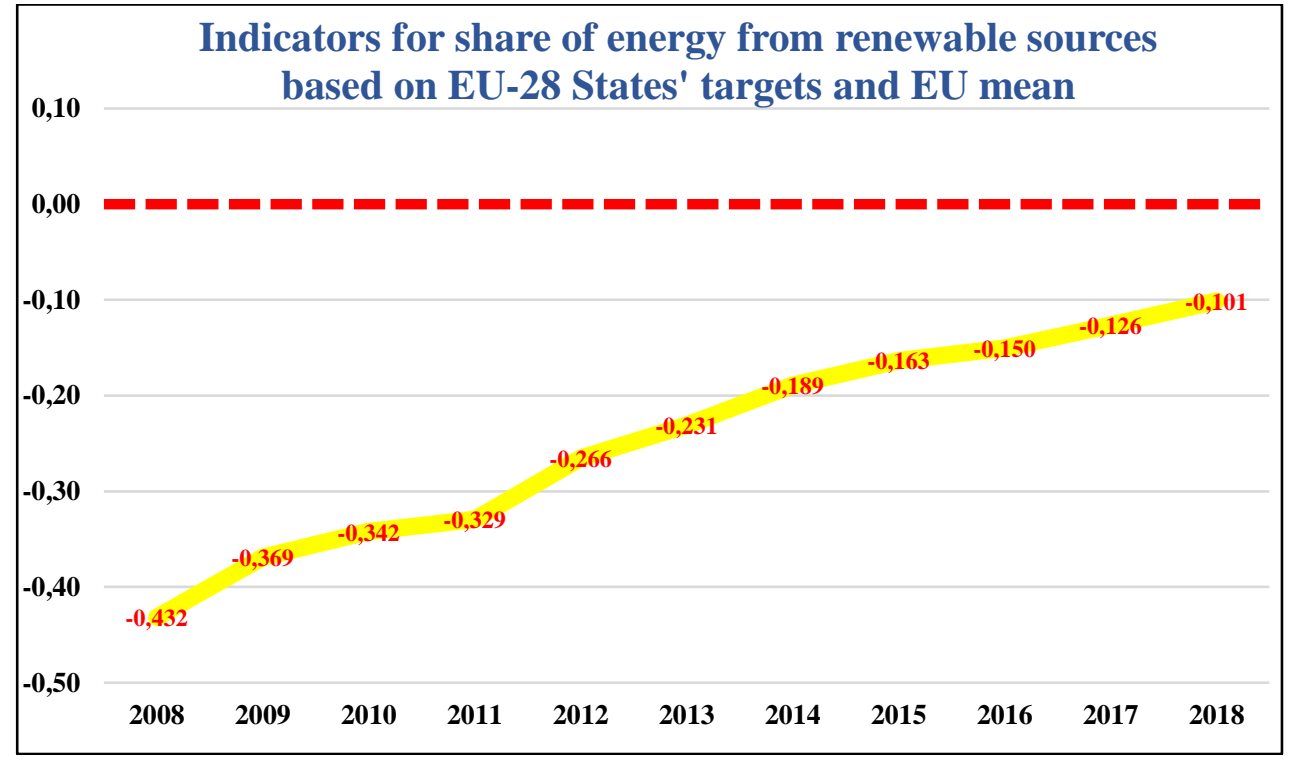

Figure 4 Indicators for share of energy from renewable sources based on EU-28 States' targets and EU mean.

Source: Author's calculations. 


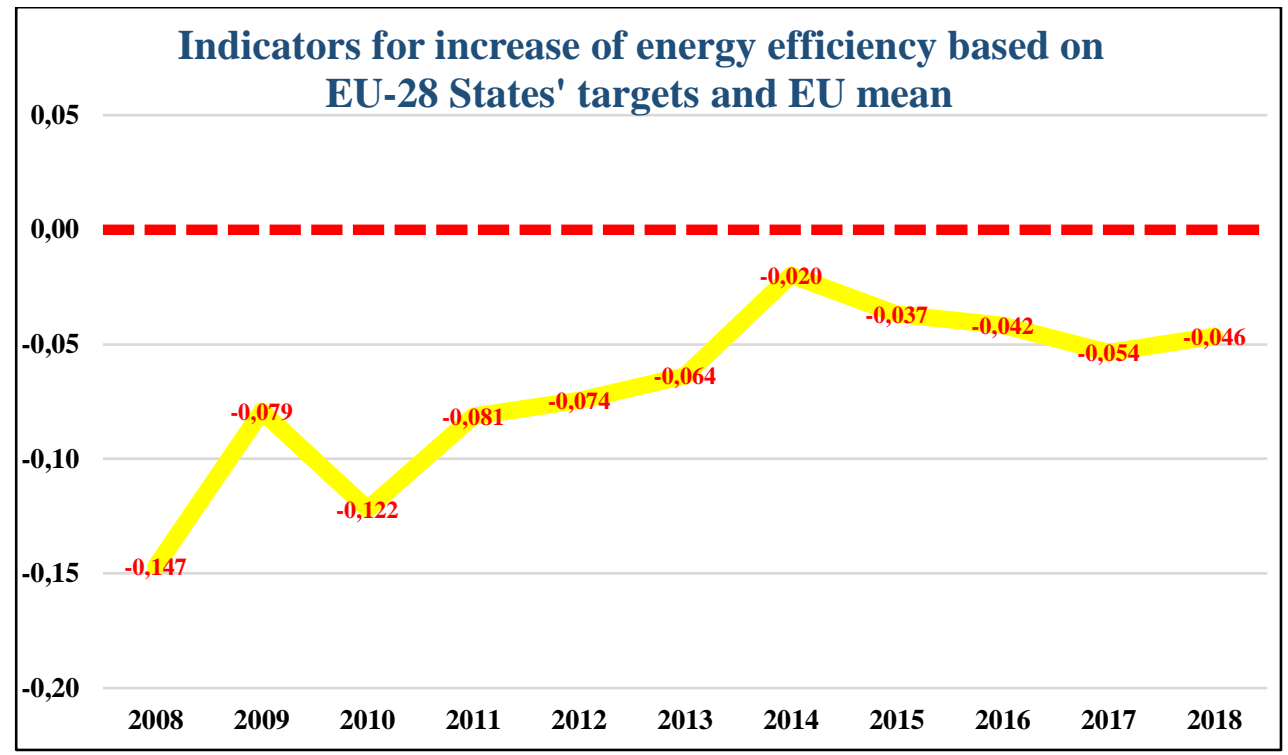

Figure 5 Indicators for increase of energy efficiency based on EU-28 States' targets and EU mean.

Source: Author's calculations

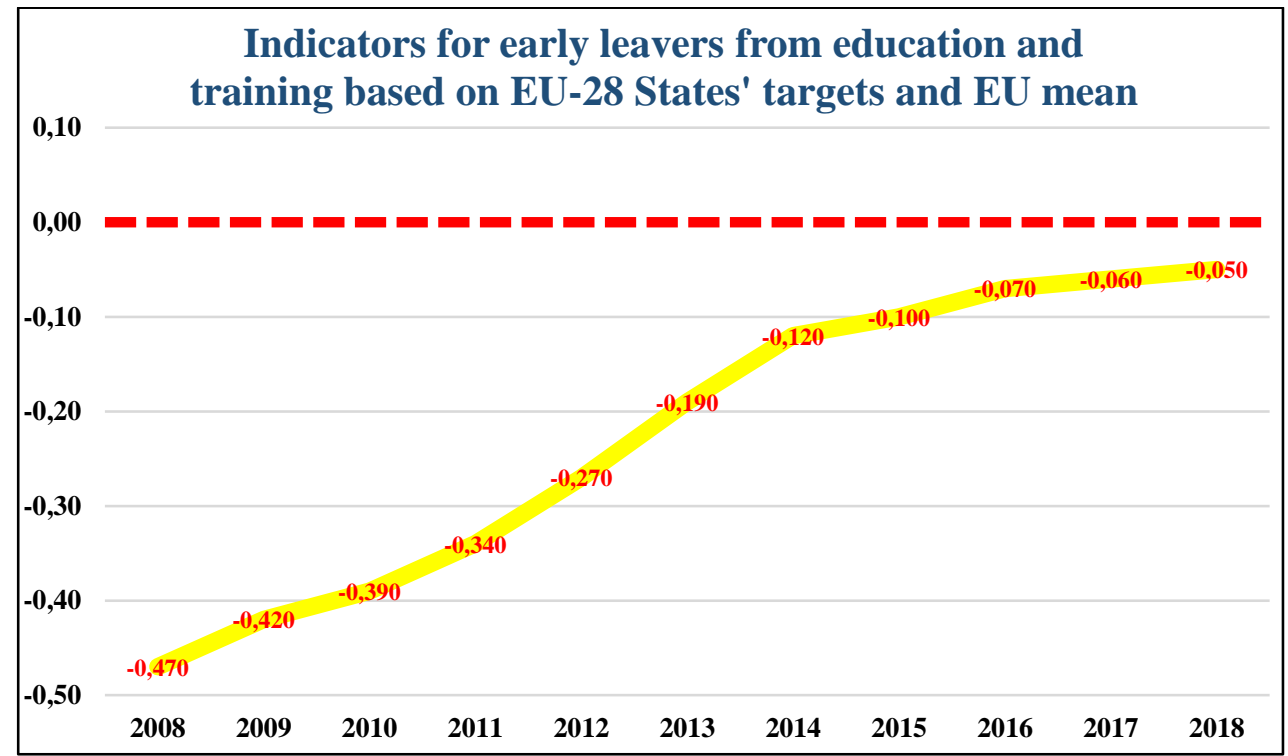

Figure 6 Indicators for early leavers from education and training based on EU-28 States' targets and EU mean.

Source Author's calculations. 


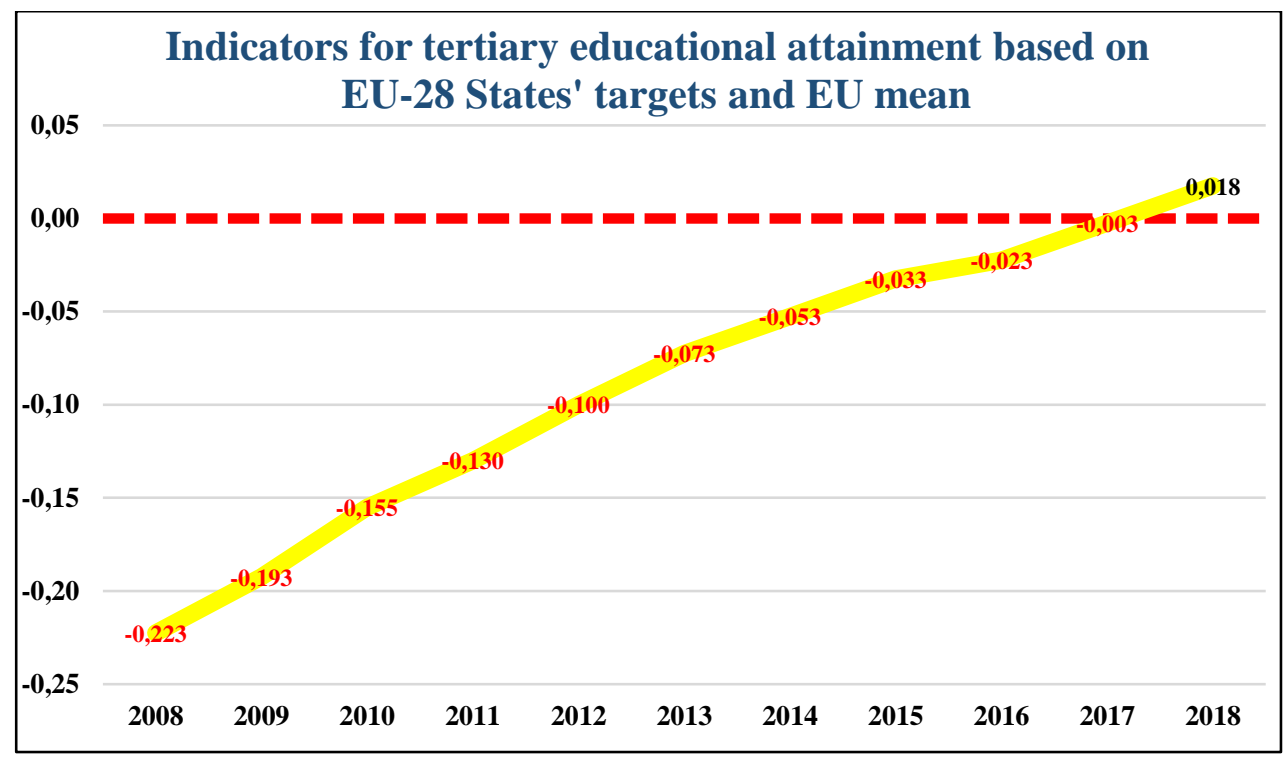

Figure 7 Indicators for tertiary educational attainment based on EU-28 States' targets and EU mean.

Source: Author's calculations

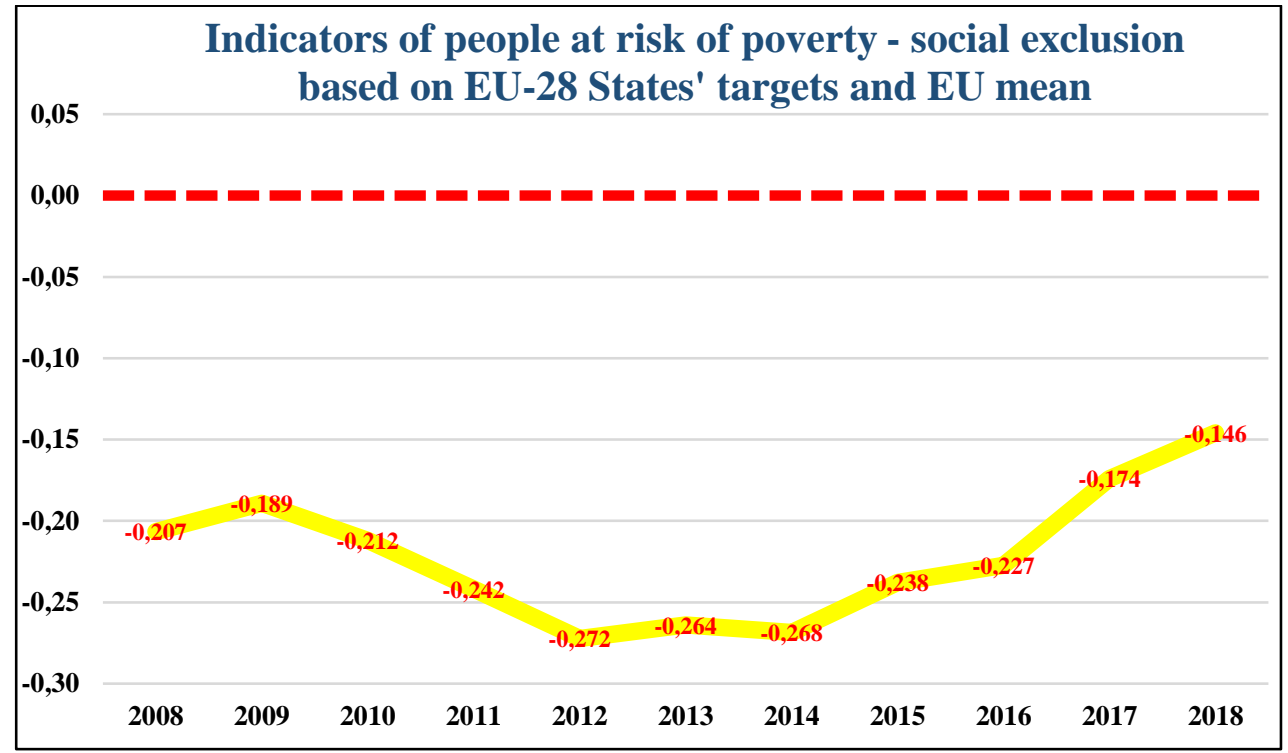

Figure 8 Indicators of people at risk of poverty - social exclusion based on EU-28 States' targets and EU mean.

Source: Author's calculations. 
Table 2 Starting and recent deviations from targets for all indicators of Strategy "Europe 2020". Source: Author's calculations

\begin{tabular}{|c|c|c|c|c|c|c|c|c|c|c|}
\hline Country Name & Years & EMP & R\&D & CLA & CLB & CLC & EDA & EDB & POV & Deviation \\
\hline \multirow{2}{*}{ Austria } & 2008 & $-0,041558$ & $-0,316489$ & $-0,098810$ & $-0,151294$ & $-0,030794$ & $-0,073684$ & $-0,423684$ & $-0,160519$ & $-0,287212$ \\
\hline & 2018 & $-0,010390$ & $-0,156915$ & $-0,060714$ & $-0,016882$ & $-0,009524$ & 0,231579 & $\mathbf{0 , 0 7 1 0 5 3}$ & $-0,032787$ & Rank: 2 \\
\hline \multirow{2}{*}{ Belgium } & 2008 & $-0,071038$ & $-0,353333$ & $-0,162353$ & $-0,723846$ & $-0,170023$ & $-0,263158$ & $-0,087234$ & $-0,209482$ & $-0,759403$ \\
\hline & 2018 & $-0,047814$ & $-0,080000$ & $-0,045882$ & $-0,275154$ & $-0,071854$ & $\mathbf{0 , 0 9 4 7 3 7}$ & 0,012766 & $-0,238699$ & Rank: 16 \\
\hline \multirow{2}{*}{ Bulgaria } & 2008 & $-0,069737$ & $-0,700000$ & $-0,007500$ & $-0,353438$ & $-0,125444$ & $-0,345455$ & $-0,247222$ & $-0,189504$ & $-0,990993$ \\
\hline & 2018 & $-0,047368$ & $-0,500000$ & $-0,008333$ & 0,283000 & $-0,086391$ & $-0,154545$ & $-0,063889$ & $-0,130466$ & Rank: 21 \\
\hline \multirow{2}{*}{ Croatia } & 2013 & $-0,090620$ & $-0,421429$ & 0,217117 & 0,402000 & 0,282511 & $-0,125000$ & $-0,268571$ & $-0,041803$ & $-0,332857$ \\
\hline & 2018 & 0,036566 & $-0,307143$ & 0,109009 & 0,401200 & 0,266368 & 0,175000 & $-0,025714$ & 0,173770 & Rank: 3 \\
\hline \multirow{2}{*}{ Cyprus } & 2008 & 0,020000 & $-0,220000$ & $-0,102105$ & $-0,605077$ & $-0,295455$ & $-0,370000$ & 0,023913 & $-0,175325$ & $-0,564051$ \\
\hline & 2018 & $-0,014667$ & $\mathbf{0 , 1 0 0 0 0 0}$ & $-0,052632$ & 0,067846 & $-0,159091$ & 0,220000 & 0,241304 & $-0,337662$ & Rank: 11 \\
\hline \multirow{2}{*}{ Czechia } & 2008 & $-0,034667$ & 0,240000 & 0,066055 & $-0,332769$ & $-0,073232$ & $-0,018182$ & $-0,518750$ & $-0,068213$ & $-0,147222$ \\
\hline & 2018 & $\mathbf{0 , 0 6 5 3 3 3}$ & 0,930000 & 0,045872 & 0,165385 & $-0,019949$ & $-0,127273$ & $\mathbf{0 , 0 5 3 1 2 5}$ & 0,137790 & Rank: 1 \\
\hline \multirow{2}{*}{ Denmark } & 2008 & $-0,016250$ & $-0,076667$ & $-0,217500$ & $-0,381833$ & $-0,144253$ & $-0,270000$ & $-0,027500$ & $-0,067692$ & $-0,526992$ \\
\hline & 2018 & $-0,031250$ & $\mathbf{0 , 0 1 0 0 0 0}$ & $-0,011250$ & 0,190267 & $-0,032184$ & $-0,040000$ & 0,210000 & $-0,412308$ & Rank: 9 \\
\hline Estonia & 2008 & 0,014474 & $-0,583333$ & $-0,069369$ & $-0,254280$ & 0,173846 & $-0,473684$ & $-0,140000$ & $-0,300000$ & $-1,235059$ \\
\hline \multirow{2}{*}{ Finland } & 2008 & $-0,028205$ & $-0,115000$ & $-0,152381$ & $-0,174684$ & 0,037047 & $-0,225000$ & 0,088095 & $-0,181818$ & $-0,586405$ \\
\hline & 2018 & $-0,021795$ & $-0,312500$ & $-0,053571$ & $\mathbf{0 , 0 8 3 2 1 1}$ & $\mathbf{0 , 0 8 1 0 5 8}$ & $-0,037500$ & $\mathbf{0 , 0 5 2 3 8 1}$ & $-0,161039$ & Rank: 13 \\
\hline \multirow{2}{*}{ France } & 2008 & $-0,068000$ & $-0,313333$ & $-0,113953$ & $-0,513609$ & $-0,161392$ & $-0,242105$ & $-0,180000$ & $-0,175912$ & $-0,923015$ \\
\hline & 2018 & $-0,049333$ & $-0,266667$ & $-0,001163$ & $-0,278565$ & $-0,086448$ & 0,063158 & $-0,076000$ & $-0,164839$ & Rank: 19 \\
\hline \multirow{2}{*}{ Germany } & 2008 & $-0,038961$ & $-0,126667$ & $-0,136047$ & $-0,439556$ & $-0,159653$ & $-0,180000$ & $-0,340476$ & $-0,245023$ & $-0,411465$ \\
\hline & 2018 & 0,037662 & $\mathbf{0 , 0 4 3 3 3 3}$ & $-0,073256$ & $-0,084389$ & $-0,054772$ & $-0,030000$ & $-0,169048$ & 0,539816 & Rank: 4 \\
\hline \multirow{2}{*}{ Greece } & 2008 & $-0,052857$ & $-0,450000$ & 0,015625 & $-0,545389$ & $-0,228745$ & $-0,440000$ & $-0,196875$ & $-0,173344$ & $-0,456728$ \\
\hline & 2018 & $-0,150000$ & $-0,016667$ & 0,252083 & $\mathbf{0 , 0 0 0 1 1 1}$ & $\mathbf{0 , 0 9 2 3 0 8}$ & $\mathbf{0 , 5 3 0 0 0 0}$ & $\mathbf{0 , 3 8 4 3 7 5}$ & $-0,290062$ & Rank: 6 \\
\hline \multirow{2}{*}{ Hungary } & 2008 & $-0,180000$ & $-0,455556$ & 0,170909 & $-0,341231$ & $-0,043983$ & $-0,170000$ & $-0,329412$ & $-0,191980$ & $-0,472314$ \\
\hline & 2018 & $-0,008000$ & $-0,150000$ & 0,180000 & $-0,039308$ & $-0,016183$ & $-0,250000$ & $-0,008824$ & 0,194966 & Rank: 7 \\
\hline \multirow{2}{*}{ Ireland } & 2008 & $\mathbf{0 , 0 6 5 2 1 7}$ & $-0,305000$ & $-0,236250$ & $-0,754438$ & $-0,125899$ & $-0,462500$ & $-0,201667$ & $-0,235294$ & $-1,253456$ \\
\hline & 2018 & $\mathbf{0 , 0 7 3 9 1 3}$ & $-0,425000$ & $-0,205000$ & $-0,308688$ & $-0,046043$ & 0,375000 & $-0,061667$ & $-0,207059$ & Rank: 24 \\
\hline \multirow{2}{*}{ Italy } & 2008 & $-0,061194$ & $-0,241830$ & $-0,085057$ & $-0,324000$ & $-0,114684$ & $-0,225000$ & $-0,261538$ & $-0,170781$ & $-0,427482$ \\
\hline & 2018 & $-0,059701$ & $-0,091503$ & 0,056322 & 0,045588 & 0,068101 & $\mathbf{0 , 0 9 3 7 5 0}$ & 0,069231 & $-0,276277$ & Rank: 5 \\
\hline
\end{tabular}




\begin{tabular}{|c|c|c|c|c|c|c|c|c|c|c|}
\hline Country Name & Years & EMP & R\&D & CLA & CLB & CLC & EDA & EDB & POV & Deviation \\
\hline \multirow{2}{*}{ Latvia } & 2008 & 0,032877 & $-0,613333$ & 0,082051 & $-0,254725$ & 0,151852 & $-0,550000$ & $-0,226471$ & $-0,195477$ & $-0,573333$ \\
\hline & 2018 & 0,052055 & $-0,573333$ & 0,081197 & 0,007300 & 0,131481 & 0,170000 & 0,255882 & 0,122779 & Rank: 12 \\
\hline \multirow{2}{*}{ Lithuania } & 2008 & $-0,010989$ & $-0,584211$ & 0,148696 & $-0,225043$ & $-0,270769$ & 0,166667 & $-0,180698$ & $-0,117936$ & $-0,536842$ \\
\hline & 2018 & 0,068681 & $-0,536842$ & 0,072174 & 0,062957 & 0,026154 & 0,488889 & 0,182752 & 0,024570 & Rank: 10 \\
\hline \multirow{2}{*}{ Luxembourg } & 2008 & $-0,057534$ & $-0,295652$ & $-0,198750$ & $-0,744091$ & $-0,024444$ & $-0,340000$ & $-0,396970$ & $-0,090909$ & $-1,840272$ \\
\hline & 2018 & $-0,012329$ & $-0,473913$ & $-0,120000$ & $-0,176455$ & 0,008889 & 0,370000 & $-0,148485$ & $-0,909091$ & Rank: 26 \\
\hline \multirow{2}{*}{ Malta } & 2008 & $-0,154286$ & $-0,735000$ & 0,046667 & $-0,980500$ & $-0,371429$ & $-1,720000$ & $-0,363636$ & $-0,088125$ & $-2,290413$ \\
\hline & 2018 & $\mathbf{0 , 0 7 8 5 7 1}$ & $-0,725000$ & $-0,256190$ & $-0,202200$ & $-0,171429$ & $-0,740000$ & 0,051515 & $-0,195594$ & Rank: 27 \\
\hline \multirow{2}{*}{ Netherlands } & 2008 & $-0,038750$ & $-0,352000$ & $-0,135714$ & $-0,743143$ & $-0,151236$ & $-0,425000$ & $-0,050000$ & $-0,104932$ & $-0,810481$ \\
\hline & 2018 & $-0,010000$ & $-0,136000$ & 0,052381 & $-0,472500$ & $-0,066063$ & $\mathbf{0 , 0 8 7 5 0 0}$ & $\mathbf{0 , 2 3 5 0 0 0}$ & $-0,125918$ & Rank: 17 \\
\hline \multirow{2}{*}{ Poland } & 2008 & $-0,084507$ & $-0,647059$ & 0,078947 & $-0,485800$ & 0,034336 & $-0,111111$ & $-0,340000$ & $-0,150135$ & $-0,713256$ \\
\hline & 2018 & 0,016901 & $-0,288235$ & $-0,062281$ & $-0,247733$ & $-0,048340$ & $-0,066667$ & 0,015556 & $\mathbf{0 , 3 0 1 7 7 2}$ & Rank: 15 \\
\hline \multirow{2}{*}{ Portugal } & 2008 & $-0,025333$ & $-0,466667$ & 0,064356 & $-0,259903$ & $-0,048444$ & $-2,490000$ & $-0,460000$ & $-0,078217$ & $-0,870593$ \\
\hline & 2018 & $\mathbf{0 , 0 0 5 3 3 3}$ & $-0,500000$ & 0,169307 & $-0,021871$ & $-0,006222$ & $-0,180000$ & $-0,162500$ & 0,130622 & Rank: 18 \\
\hline \multirow{2}{*}{ Romania } & 2008 & $-0,080000$ & $-0,725000$ & 0,147059 & $-0,158167$ & 0,132093 & $-0,407080$ & $-0,400749$ & $-0,067955$ & $-1,281616$ \\
\hline & 2018 & $-0,001429$ & $-0,745000$ & 0,173109 & $-0,005208$ & 0,244651 & $-0,451327$ & $-0,078652$ & 0,254833 & Rank: 25 \\
\hline \multirow{2}{*}{ Slovakia } & 2008 & $-0,044444$ & $-0,616667$ & 0,141593 & $-0,448357$ & $-0,035366$ & 0,000000 & $-0,605000$ & $-0,197674$ & $-0,941119$ \\
\hline & 2018 & 0,005556 & $-0,300000$ & 0,154867 & $-0,150286$ & 0,037195 & $-0,433333$ & $-0,057500$ & 0,052326 & Rank: 20 \\
\hline \multirow{2}{*}{ Slovenia } & 2008 & $-0,026667$ & $-0,456667$ & $-0,044231$ & $-0,400200$ & $-0,026027$ & $-0,020000$ & $-0,227500$ & $-0,124611$ & $-0,519616$ \\
\hline & 2018 & $\mathbf{0 , 0 0 5 3 3 3}$ & $-0,350000$ & 0,107692 & $-0,154040$ & 0,086301 & 0,160000 & 0,067500 & $-0,015576$ & Rank: 8 \\
\hline \multirow{2}{*}{ Spain } & 2008 & $-0,074324$ & $-0,335000$ & $-0,096667$ & $-0,463150$ & $-0,122204$ & $-1,113333$ & $-0,061364$ & $-0,149158$ & $-1,155466$ \\
\hline & 2018 & $-0,094595$ & $-0,380000$ & 0,045556 & $-0,127350$ & $-0,040317$ & $-0,193333$ & $-0,036364$ & $-\mathbf{0 , 2 8 3 5 0 7}$ & Rank: 22 \\
\hline \multirow{2}{*}{ Sweden } & 2008 & 0,005000 & $-0,127500$ & $-0,107229$ & $-0,088449$ & $-0,094240$ & $-0,128571$ & $-0,066667$ & $-0,192857$ & $-0,607523$ \\
\hline & 2018 & 0,030000 & $-0,172500$ & 0,093976 & 0,115204 & $-0,077880$ & $-0,071429$ & 0,151111 & $-0,285714$ & Rank: 14 \\
\hline \multirow{2}{*}{$\begin{array}{l}\text { United } \\
\text { Kingdom }\end{array}$} & 2008 & & & $-0,091667$ & $-0,820467$ & $-0,192568$ & & & & \multirow{2}{*}{ Undefined } \\
\hline & 2018 & & & 0,061905 & $-0,265533$ & 0,007489 & & & & \\
\hline \multirow{2}{*}{ EU evolutive } & 2008 & $-0,064000$ & $-0,390000$ & $-0,208750$ & $-0,431600$ & $-0,146952$ & $-0,470000$ & $-0,222500$ & $-0,206549$ & \multirow{2}{*}{$-0,769601$} \\
\hline & 2018 & $-0,024000$ & $-0,293333$ & $-0,108750$ & $-0,101150$ & $-0,046473$ & $-0,050000$ & 0,017500 & $-0,145894$ & \\
\hline
\end{tabular}





\section{REFERENCES}

1. Aggelopoulos A., Komninos D., Dermatis Z., Anastasiou A. and Liargovas P. (2018) 'Solid Waste Generation in Europe: Study of Affecting Factors Using Panel Data', Research in World Economy, Vol 9 (1), 77-84.

2. Anastasiou A. and Pasiopoulou M. (2020) 'Sustainable Development at the frames of the Strategy “Europe 2020”', Theoretical Economics Letters, Vol. 10, 443-457.

3. European Commission (2010). Europe 2020 - A European strategy for smart, sustainable and inclusive growth, Communication from the Commission, COM (2010) 2020, Brussels, 3.3.2010

4. European Commission (2012). "Europe 2020: Europe's growth strategy”, The European Union Explained, European Commission President Barroso, June 2012

5. European Commission (2014). Taking stock of the Europe 2020 strategy, for smart, sustainable and inclusive growth, Communication from the Commission, COM (2014) 130, Brussels, 19.3.2014

6. European Commission (2020). "The European Semester", Available at https://ec.europa.eu/info/business-economy-euro/economic-and-fiscal-policycoordination/eu-economic-governance-monitoring-prevention-correction/europeansemester_en

7. Eurostat (2019). Smarter, greener, more inclusive? Indicators to support the Europe 2020 Strategy, September 2019

8. Fischer, S., Gran, S., Hacker, B., Jakobi, A.P., Petzold, S., Pusch, T., Steinberg, P., (2010). “"Europe 2020’ Proposals for the Post-Lisbon Strategy - Progressive policy proposals for Europe's economic, social and environmental renewal, International Policy Analysis, Berlin, May 2010

9. Gros, D., Roth, F., (2012). The Europe 2020 Strategy - Can it Maintain the EU's Competitiveness in the World?, Centre for European Policy Studies, Brussels, 2012

10. Hacker, B., Treeck, T., (2010). What influence for European governance? - The Reformed Stability and Growth Pact, the Europe 2020 Strategy and the 'European Semester' International Policy Analysis, Berlin, December 2010

11. Lyroni A., Anastasiou A., Liargovas P., Dermatis Z. and Komninos D. (2018) 'Factors Affecting the Relationship between Research and Development (R \& D) and Economic Development in EU', Advances in Economics and Business, Vol 6 (5), 322-331.

12. Papailiou P., Komninos D., Dermatis Z., Anastasiou A. and Liargovas P. (2018) 'Intelligent Growth and Macroeconomic Performance of EU Member Countries in the Framework of Europe 2020', Applied Economics and Finance, Vol 5 (4), 117-126.

13. Zavou A., Anastasiou A., Liargovas P., Dermatis Z. and Komninos D. (2018) 'Trade flows and Economic Growth between countries - members of the European Union', Noble International Journal of Economics and Financial Research, Vol 3 (7), 78-85. 